\title{
BIBLIOGRAFIJA PROF. DR. VLADIMIRJA KLEMENČIČA ZA OBDOBJE 1952-1996
}

\author{
Mojca Dolgan-Petrič, Ida Knez-Račič, Janja Turk
}

Uredništvo geografske publikacije Dela Oddelka za geografijo na Filozofski fakulteti v Ljubljani je ob 70-letnici prof. dr. Vladimirja Klemenčiča želelo predstaviti bogato publicistično dejavnost jubilanta. $\mathrm{V}$ knjižnici smo $\mathrm{v}$ ta namen pripravili bibliografijo prof. dr. Vladimirja Klemenčiča od prvih objav leta 1952 do konca leta 1996.

Bibliografija, ki je pred vami, ni popoln prerez znanstvenega, mentorskega, uredniškega in drugega strokovnega dela prof. Vladimirja Klemenčiča, vendar se že iz predstavljenega opusa objavljenih znanstvenih in strokovnih del kaže njegov bogat prispevek $\mathbf{k}$ razvoju slovenske geografije in uveljavitvi stroke doma in po svetu.

Bibliografijo smo sestavili s pomočjo dveh osnovnih virov: listkovnega kataloga in računalniškega kataloga (bibliografske baze GEOFF) Knjižnice Oddelka za geografijo na Filozofski fakulteti v Ljubljani. Gradivo smo dopolnili s podatki iz publikacije Biografije in bibliografije univerzitetnih učiteljev in sodelavcev Univerze v Ljubljani, knjige 1-4, ter vzajemnega kataloga slovenskih knjižnic COBIB.

Bibliografija obsega 283 tiskanih, doma in v tujini objavljenih bibliografskih enot. Upoštevani so znanstveni in strokovni članki iz strokovnih revij, sestavki iz zbornikov posvetovanj in kongresov ter samostojne publikacije (monografije).

Bibliografija ne vključuje raziskovalnih nalog, elaboratov in ekspertiz. Iz bibliografije smo izločili članke iz časnikov ter recenzije, ocene in poročila. $V$ bibliografiji ni zabeleženo uredniško delo ter bogato mentorsko delo pri diplomah, magistrskih nalogah in doktorskih disertacijah.

Bibliografija je urejena kronološko, znotraj posameznih let pa so prispevki urejeni po abecednem vrstnem redu.

1952

Agrarna geografija Tuhinjske doline. - Geografski zbornik 1 (1952), str. 75-120.

Rast prebivalstva na Slovenskem Koroškem v obdobju 1934-1951. - Geografski vestnik 24 (1952), str. 115-134. 
Urbanizacija okolice Kamnika. - Geografski vestnik 25 (1953), str. 73-92.

1954

Pomen popisov prebivalstva leta 1948 in 1953 za geografijo prebivalstva Slovenije. - Geografski vestnik 26 (1954), str. 187-190.

Razvoj Mengša v zadnjem stoletju. -V: Mengeški zbornik. Mengeš 1954, str. 92-98.

1959

Migracije prebivalstva na Koroškem med 1934 do 1951. - V: Zbornik Koroške. Ljubljana 1959, str. 92-112.

Pokrajina med Snežnikom in Slavnikom : gospodarska geografija. - Ljubljana 1959, 197 str. (Dela / Slovenska akademija znanosti in umetnosti. Razred za prirodoslovne in medicinske vede ; 8).

Poskus gospodarsko-geografske klasifikacije naselij Slovenije. - V: Zbornik radova 5. kongresa geografa FNR Jugoslavije održanog u NR Crnoj gori od 8 - 16 septembra 1958. Cetinje 1959, str. 485-487.

1960

Kritični pretres avstrijskega popisa $1951 \mathrm{z}$ ozirom na jezikovno strukturo na Koroškem. - Razprave in gradivo 1960, št. 2, str. 101-182.

Problemi gospodarsko-geografske klasifikacije slovenskih naselij. - Geografski vestnik 32 (1960), str. 111-130.

Geografski problemi i metode proučevanja svakodnevnog putovanja radne snage od mesta stanovanja na rad i obratno. - V: Zbornik 6. kongresa geografov FLRJ. Ljubljana 1962, str. 291-296. 
Kmetijska proizvodnja in izraba tal v vasi Podgorje pri Kamniku. - Geografski vestnik 34 (1962), str. 26-81.

Rast prebivalstva novomeške pokrajine po letu 1869. - V: Dolenjska zemlja in ljudje. Novo mesto 1962, str. 162-174. (soavtorji M. Dobovšek .[et al.])

\section{3}

Dnevni priliv delovne sile v industrijska podjetja Ljubljane v letih 1951 in 1961. Geografski vestnik 35 (1963), str. 3-13.

\section{4}

Die geographischen Probleme der Almwirtschaft in Jugoslawien. - V: Almgeographie. Wiesbaden 1964, str. 43-55. (Forschungsberichte ; 4).

Predhodni rezultati proučevanja najnovejših geografskih procesov slovenske pokrajine. - Geografski obzornik 11 (1964), št. 2, str. 55-56.

Transformacija prigradske zone. - V: Zbornik 7. kongresa geografa SFRJ. Zagreb 1964, str. 189-209.

Zakaj nazaduje interes za obdelavo zemlje? - Socialistično kmetijstvo in gozdarstvo 15 (1964), št. 17, str. 426.

\section{5}

Mednarodna konferenca za metode proučevanja izrabe tal v Budimpešti in mednarodna konferenca v Halle-u v letu 1964. - Geografski vestnik 37 (1965), str. 178-179.

Nekateri elementi sodobnega socialno-geografskega procesa v Sloveniji. Socialistično kmetijstvo in gozdarstvo 16 (1965), št. 7, str. 181-182 in št. 8, str. 207.

Razvoj in rezultati agrarne geografije $\mathbf{v}$ Jugoslaviji. - Geografski obzornik 12 (1965), št. 1, str. 15-22. (soavtor I. Crkvenčić)

Regionalni procesi in kmetijstvo Slovenije. - Teorija in praksa 2 (1965), št. 4, str. 604-614. 
The village of Podgorje in the Slovenian Sub-Alpine region. - Geographia Polonica 1965, št. 5, str. 195-214.

Za objektivno in konstruktivno kritiko. - Geografski obzornik 12 (1965), št. 1, str. 26-30. (soavtorji M. Jeršič ...[et al.])

\section{6}

Agrogeografičeskie issledovanija v Jugoslavii. - Vestnik Moskovskogo universiteta 1966, št. 4, str. 34-39. (soavtor I. Crkvenčić)

Some elements of urbanization and regional development of Slovenia. - V: Aspects of the study of regional geographical structure. Bratislava 1966, str.145-174. (Acta geologica et geographica Universitatis Comenianae. Geographica ; 6).

\section{7}

Arbeitsrichtungen und -ergebnisse der Agrargeographie in Jugoslawien. Wissenschaftliche Zeitschrift der Universität Halle 16 (1967), str. 201-211. (soavtor I. Crkvenčić)

Elementi transformacije Bistriške ravnine. - V: Kamniški zbornik. Kamnik 1967, str. 3-46. (soavtor M. Jeršič)

The mapping of land utilization in Yugoslavia. - V: Land utilization in Eastern Europe. Budapest 1967, str. 67-73 . (Studies in geography in Hungary ; 4). (soavtor I. Crkvenčić)

Razvoj i rezultati agrarne geografije u Jugoslaviji. - V: Zbornik radova prvog jugoslavenskog simpozija o agrarnoj geografiji u Mariboru od 3. do 5. decembra 1964. Ljubljana 1967, str. 27-45. (soavtor I. Crkvenčić)

Rezultati agrarno geografskih proučavanja Instituta za geografiju Univerze u Ljubljani u godinama 1962-1964. - V: Zbornik radova prvog jugoslavenskog simpozija o agrarnoj geografiji u Mariboru od 3. do 5. decembra 1964. Ljubljana 1967, str. 73-83.

\section{8}

Mešovita struktura domaćinstava poljoprivrednih gazdinstava kao elemenat socijalno geografskih procesa i transformacije pokrajine. - V: Zbornik na 8. 
kongres na geografite od SFRJ vo Makedonija od 9. 9. do 14. 9. 1968. Skopje 1968, str. 297-310.

Migracije stanovništva u Sloveniji. - V: Cvijićev zbornik. Beograd 1968, str. 199206.

Probleme und Versuche von kartographischen Analysen der Bodennutzung in Slowenien. - V: Internationale Beratung über Bodennutzungskarten. Budapest 1968, str. 211-218.

Problemi mešane strukture gospodinjstev in kmečkih gospodarstev v Sloveniji : prispevek k študiju urbanizacije. - Geografski vestnik 40 (1968), str. 19-49.

Slovenija in Slovenci $v$ mreži interdisciplinarno organiziranega raziskovalnega dela znanstvenih inštitucij $\mathbf{v}$ tujini. - V: Dokumentacija univerzitetne konference ZKS. Ljubljana 1968, str. 25-31.

Sozialgeographische Probleme der Arbeiter-Bauern-Strukturen unter besonderer Berücksichtigung der Situation in Jugoslawien. - V: Zum Standort der Sozialgeographie. München 1968, str. 75-82. (Münchner Studien zur Sozial- und Wirtschaftsgeographie ; 4).

Transformacija na selskoto stopanstvo $\mathbf{i}$ iskoristuvanje na zemljišteto vo Golozinci. - Geografski razgledi 6 (1968), str. 38-54. (soavtorja M. Panov, M. Pak)

Ekskurzija v Podjuno. - V: Povzetki referatov v sekcijah in vodnik po poti ekskurzij. 8. zborovanje slovenskih geografov na Ravnah na Koroškem, 12. - 14. septembra 1969. Ljubljana 1969, str. 41-45.

Elemets of the transformation of the Bistrica plain. - V: Exursion guide and some studies of land utilization in Slovenia. 3. Conference of Sub-Committe of Land Utilization in the East-European Countries at Maribor from 7th - 11th October 1969. Ljubljana 1969, str. 59-62. (soavtor M. Jeršič)

Izseljevanje, problem Slovenije in Slovencev. - V: Draga 1968. Predavanja študijskih dni v Dragi pri Trstu. Trst 1969, str. 51-59.

The land utilization and the agrarian economic systems of the cadastrian parish of Sečovlje. - V: Exursion guide and some studies of land utilization in Slovenia. 3. 
Conference of Sub-Committe of Land Utilization in the East-European Countries at Maribor from 7th - 11th October 1969. Ljubljana 1969, str. 73-77.

Nekateri elementi gospodarsko-geografskega razvoja Rakitne. - Geografski vestnik 41 (1969), str. 39-57. (soavtor M. Pak)

Pomen hitre ceste za razvoj dnevne migracije. - V: Narodnogospodarski vidiki izgradnje hitre ceste Šentilj-Gorica. Ljubljana 1969, str. 91-93.

Temeljna vprašanja slovenske univerze ob njeni petdesetletnici. - Sodobnost 17 (1969), št. 12, str. 1195-1197.

\section{0}

Ein am Beispiel von Slowenien vorgenommener Versuch einer Klassifikation von Gemeinden, von räumlicher Differenzierung nach der Bevölkerungsmobilität. Geographical papers 1 (1970), str. 129-143.

Inventarizacija procesa u prostoru za potrebe regionalnog planiranja industrijskog društva. - V: Geodetska delatnost u oblasti inventarizacije prostora. Bled 1970, str. 173-178.

The migration of population and the industrialization of Slovenia. - V: Recent population movements in the East-European countries. Budapest 1970, str. 21-27. (Studies in geography in Hungary ; 7).

Problemi socialne in prostorske mobilnosti Slovencev. - V: 6. seminar slovenskega jezika, literature in kulture, 29. 6. - 11. 7. 1970. Ljubljana 1970, str. 17-26.

Selitveni tokovi prebivalstva v Sloveniji. - V: Slovenski izseljenski koledar 17 (1970), str. 49-52.

Sodobni problemi regionalnega razvoja Krasa in perspektive njenega nadaljnjega razvoja $=$ Problemi sullo stato attuale del Carso e prospettive per il suo futuro sviluppo. - V: Akti študijskega srečanja o Krasu, Veliki Repen (Trst), 7. septembra 1970 = Atti del Convegno di studio sul patrimonio Carsico, Rupingrande (Trieste), 7 settembre 1970. Trst 1970, str. 9-13.

Zur historischen Geographie Istriens. - Österreichische Osthefte 12 (1970), št. 4, str. 278-279. 
Industrializacija in socialni razvoj Slovenije po drugi svetovni vojni. - V: Slovenski izseljenski koledar 18 (1971), str.70-73.

Prostorska diferenciacija Slovenije po selitveni mobilnosti prebivalstva. Geografski zbornik 12 (1971), str. 135-220.

Sodobni problemi regionalnega razvoja Krasa in perspektive njenega nadaljnjega razvoja. - V: Jadranski koledar 1971. Trst 1971, str. 205-208.

Spreminjanje gospodarske in socialne strukture in narodnostni problemi Slovencev na Južnem Koroškem. - V: Koroška in koroški Slovenci. Maribor 1971, str. 60-69.

Types of the areas of the emptying or concentrating population in Slovenia Yugoslavia. -

Geografisk Tijdskrift 5 (1971), št. 4, str. 496-500.

1972

Geografija prebivalstva Slovenije. - Geografski vestnik 44 (1972), str. 133-142.

Geografsko opredeljivanje i problemi socialno ugroženih područja na primeru Slovenije. -

V: Zbornik na jugoslovenskiot simpozium za problemite na selskite naselbi i zemljodelskoto proizvodstvo. Ohrid 1972, str. 33-40.

Izkoriščanje zemlje. - V: Zelena knjiga o ogroženosti okolja v Sloveniji. Ljubljana 1972, str. 15-17.

Koroška : karta in imenik slovenskih in nemških krajevnih imen $=$ Landkarte und Ortschaftsverzeichnis mit slowenischen und deutschen Ortsnamen. - Maribor 1972,59 str.

Obmejna regija Slovenija in njeni regionalno prostorski problemi. - V: Mednarodni simpozij o regionalnem prostorskem planiranju, Ljubljana, 18. in 19. maj 1972. Ljubljana 1972, str. 70-74.

Razgovor uredništva Zdravstvenega vestnika $\mathrm{z}$ dr. Vladimirjem Klemenčičem. Zdravstveni vestnik 41 (1972), str. 35-38. 
The social-geographical factors in forming the types of land utilization. - V: Agricultural typology and land utilization. Verona 1972, str. 53-61. (soavtor I. Crkvenčić)

\section{3}

Deset let Inštituta za geografijo Univerze v Ljubljani 1962-1972. - Raziskovalec 3 (1973), št. 3, str. 71-74.

Einige sozialgeographische Probleme der Grenzlage Sloweniens im Jugoslawien. - V: Probleme grenznaher Räume. Innsbruck 1973, str. 13-23. (Schriftenreihe des Institutes für Städtebau und Raumordnung ; 1).

Raumdifferenzierung und Zerfall der alten klassischen Agrarstruktur der Bevölkerung in Slowenien / Jugoslawien. - V: Sozialgeographische Probleme Südeuropas. München 1973, str. 53-61. (Münchner Studien zur Sozial- und Wirtschaftsgeogeographie ; 7).

Savremeni problemi na Koruškite Slovenci kao narodnost vo Avstrija. Geografski vidik 4 (1973), str. 55-66.

Socialno-geografsko proučevanje Prekmurja na primeru k. o. Cankova in k. o. Skakovci. -

V: Mednarodni mladinski raziskovalni tabori 1971-1972. Ljubljana 1973, str. 228247.

Socijalno geografski aspekti izučavanja turizma u Sloveniji. - V: Geografija i turistička praksa. Referati sa 1. jugoslovenskog simpozijuma iz turističke geografije, održan 28. i 29. oktobra 1971. godine u Bukovičkoj banji. Beograd 1973, str. 135138. (Posebna izdanja / Prirodno-matematički fakultet Univerziteta u Beogradu, Odsek za geografske nauke, Institut za turizam i prostorno planiranje ; 2).

Sodobni socialnogeografski problemi Slovencev na Koroškem. - Geografski obzornik 20 (1973), št. 3-4, str. 2-14.

Tendence socialnega razvoja Severovzhodne Slovenije v primerjavi s celotno SR Slovenijo. - V: Geografski simpozij o Severovzhodni Sloveniji, Maribor, 13. do 15. oktobra 1972. Ljubljana 1973, str. 183-193. (Geographica Slovenica ;2).

Topical problems of open boundaries Slovenia. - V: Confini e regioni. Trieste 1973, str. 123-133. (soavtor M. Jeršič) 
Zur Raumrelevanz der Grundfunktionen im wirtschaftsgeographischen Strukturmuster Sloweniens. - V: Sozialgeographische Probleme Südeuropas. München 1973, str. 63-73. (Münchner Studien zur Sozial- und Wirtschaftsgeographie ; 7). (soavtor K. Ruppert)

\section{4}

Deset let Inštituta za geografijo Univerze v Ljubljani. - V: Socialnogeografski aspekti socialnega razlikovanja med slovenskimi pokrajinami. Ljubljana 1974, str. 719. (Geographica Slovenica ; 3).

Gli appartenenti alla nazionalita italiana nella R. S. di Slovenia nei censimenti della popolazione del 1961 e del 1971. - V: Atti. 4. incontro geografico italo-sloveno, Pordenone, 28 - 29 ottobre 1973. Parte 1. Le minoranze etnico-linguistiche della frontiera italo-jugoslava. Udine 1974, str. 119-140. (Pubblicazioni dell'Istituto di geografia della Facolta di lingue e letterature straniere dell'Universita di Trieste ; 1).

Kritični pretres avstrijskega popisa $1951 \mathrm{z}$ ozirom na jezikovno strukturo na Koroškem. -

V: Komunikacije. 1. slovenski demografski simpozij. Ljubljana 1974, 7 str.

Odprta meja med Jugoslavijo in Italijo in vloga manjšin. - Teorija in praksa 11 (1974), št. 9-10, str. 928-936.

Problemi mešane strukture gospodinjstev in kmečkih gospodinjstev v Sloveniji. V: Komunikacije. 1. slovenski demografski simpozij. Ljubljana 1974, 52 str.

Regionalne razlike in problemi demografske in poselitvene strukture Slovenije. V: Komunikacije. 1. slovenski demografski simpozij. Ljubljana 1974, 20 str.

Regionalni in demografski razvoj na območju občin Šentjur pri Celju in Šmarje pri Jelšah. - V: Voglajnsko-Sotelska Slovenija. 9. zborovanje slovenskih geografov, Rogaška Slatina 1973. Ljubljana 1974, str. 125-141.

Sodobni problemi narodnih manjšin v luči prostorske urbanizacije. - Razprave in gradivo 1974, št. 6, str. 136-140.

Sodobni problemi narodnih manjšin v luči prostorske urbanizacije. - Sodobnost 22 (1974), št. 8-9-10, str. 774-778. 
Sovremenite geografski problemi na Slovenija i Slovencite. - Zbornik na naučniot sobir po povod na 25. god GDM. Skopje 1974, str. 51-60. (Posebno izdanie / Geografsko društvo na SR Makedonija ; 1).

Agrarian-geographical research work in Yugoslavia since the conference in Budapest in 1964. - V: Izraba tal v Vzhodno-srednje evropskih deželah. 3. konferenca podkomisije za izrabo tal v Vzhodno-srednje evropskih deželah, Maribor, 7. - 11. oktober 1969. Ljubljana 1975, str. 9-23. (Geographica Slovenica ; 4). (soavtor I. Crkvenčić)

Elements of the transformation of the Bistrica plain. - V: Izraba tal $\vee$ Vzhodnosrednje evropskih deželah. 3. konferenca podkomisije za izrabo tal v Vzhodno-srednje evropskih deželah, Maribor, 7. - 11. oktober 1969. Ljubljana 1975, str. 112-114. (Geographica Slovenica ; 4). (soavtor M. Jeršič)

Indicators of the urbanization of agrarian settlements in Slovenia, Yugoslavia. V: Urbanization in Europe. Budapest 1975, str. 271-278.

Italijansko prebivalstvo na narodnostno mešanem ozemlju na Koprskem v SR Sloveniji. - V: Slovenci v Italiji po drugi svetovni vojni. Ljubljana 1975, str. 304-311.

Kétnyelvüség a Szlovén Szocialista Köztársaságban (a szlovének és magyarok által lakott, nemzetiségileg vegyes területeken). - V: Naptár` 76. A szlovéniai magyarok szemléje. Murska Sobota 1975, str. 48-63.

The land utilization and the agrarian economic systems of the cadastrian parish of Sečovlje. - V: Izraba tal $v$ Vzhodno-srednje evropskih deželah. 3. konferenca podkomisije za izrabo tal v Vzhodno-srednje evropskih deželah, Maribor, 7. - 11. oktober 1969. Ljubljana 1975, str. 122-124. (Geographica Slovenica ; 4).

O delu Inštituta za geografijo Univerze v Ljubljani v letu 1974. - Geografski vestnik 47 (1975), str. 226-227.

Vzgojna in raziskovalna dejavnost ljubljanske univerze $v$ luči potreb zamejskih Slovencev ter italijanske in madžarske narodnosti v SR Sloveniji. - V: Univerza v Ljubljani ob tridesetletnici osvoboditve 1945-1975. Ljubljana 1975, str. 47 - 49.

Zur sozioökonomischen Entwicklung in den slowenischen Alpen. - V: Die Zukunft der Alpen I. Bevölkerung, Wirtschaft, Umwelt. München 1975, str. 63-69. (Schriftenreihe ; 4). 
Amtliche österreichische Volkszählungen nach dem zweiten Weltkrieg mit Bezug auf die slowenische Minderheit und Slowenisch als Umgangssprache im Lichte des Gesetzes über die Volkszählung besonderer Art. - V: Aktuelle Fragen der slowenischen und der kroatischen Minderheit in Österreich. Ljubljana, Zagreb 1976, str. 49-60.

Drugačna dvojezičnost : o jezikovnih pravicah madžarske narodnostne skupnosti v Sloveniji. - Dan 6 (1976), št. 52, str. 24-26. (soavtor F. Hajós)

Dvojezičnost v SR Sloveniji (na narodnostno mešanem ozemlju v Prekmurju). Teorija in praksa 13 (1976), št. 1-2, str. 66-76. (soavtor F. Hajós)

Geografičeskoe izučenie izmenii socialno-ekonomičeskogo prostranstva i urbanizacii u Jugoslavii (posle 1965 g.). - V: Teritorialnaja struktura narodnogo hozjajstva u socialističeskih stranah. 23. meždunarodnij geografičeskij kongress. Moskva 1976, str. 160-171.

Kétnyelvüség a Szlovén Szocialista Köztársaságban : a szlovének és magyarok által lakott, nemzetiségileg vegyes területeken. - Nemzetközi néprajzi nemzetiségkutató konferencia, Békéscsaba, 1975. október 28 - 31. Békéscsaba 1976, str.195-211. (soavtor F. Hajós)

Kritika uradnih avstrijskih popisov prebivalstva v letih 1951, 1961 in 1971 glede na slovensko manjšino in slovenščino kot občevalni jezik. - Razprave in gradivo 1976, št. 7-8, str. 101-124.

Die Lage der Geographie in Slowenien. - V: Sozialgeographische Fragestellungen. Frankfurt am Main 1976, str. 179-181. (Materialien / Geographishes Institut der Universität Frankfurt ; 5).

O položaju slovenske geografije. - Geografski vestnik 48 (1976), str. 3-7.

The official Austrian censuses in 1951, 1961 and 1971 concerning the Slovene minority and the Slovene language as the language of communication. - V: Twenty years overdue. Slovene and Croat minorities in Austria. Ljubljana 1976, str. 19-23.

Official Austrian post-war population censuses concerning the Slovene minority and the Slovene language as the language of communication in the light of the 
act on the census of a special kind. - V: Actual questions of the Slovene and Croat minorities in Austria. Ljubljana 1976, str. 45-55.

The open border and border regions as a new regional-geographic phenomenon. - V: Regional geography. 23. International Geographical Congress, Section 8. Moskva 1976, str. 146-150.

Slovenska in italijanska narodna manjšina $v$ luči urbanizacije in odprte jugoslovansko-italijanske državne meje. - Geografski obzornik 23 (1976), št. 3-4, str. 3-11.

Slovenska manjšina v Avstriji : ob popisu prebivalstva posebne vrste leta 1976. Teorija in praksa 13 (1976), št. 11, str. 915-924.

Uradni avstrijski popisi prebivalstva po drugi svetovni vojni glede na slovensko manjšino in slovenščino kot občevalni jezik v luči zakona o popisu prebivalstva posebne vrste. - V: Sodobna vprašanja slovenske in hrvaške manjšine v Avstriji = Suvremena pitanja slovenske i hrvatske manjine u Austriji. Ljubljana 1976, str. 41-50.

\section{7}

Inštitut za geografijo Univerze $\mathbf{v}$ Ljubljani $\mathbf{v}$ jubilejnem petnajstem letu dela (1976). - Geografski vestnik 49 (1977), str. 233-238.

Manipulacije s statističnimi podatki v škodo manjšin v Avstriji. - V: Problem manjšin v jugoslovansko avstrijskih odnosih. Beograd 1977, str. 117-133.

Manipulacije sa statističkim podacima na štetu manjina u Austriji. - V: Problem manjina u jugoslavensko austrijskim odnosima. Beograd 1977, str. 106-122.

Manipulation mit statistischen Daten zum Nachteil der Minderheiten in Österreich. - V: Das Minderheitsproblem in den jugoslawisch-österreichischen Beziehungen. Beograd 1977, str. 143-162.

Manipulation of statistical data to the damage of minorities in Austria. - V: Minority problems in Yugoslav Austrian relations. Beograd 1977, str. 123-140.

Neki aspekti teoretskog razvitka i društvene funkcije geografije u Sloveniji. - V: Zbornik 10. jubilarnog kongresa geografa Jugoslavije, održanog u Srbiji od 15. do 20. 9. 1976. Beograd 1977, str. 43-47. 
Položaj slovenačke manjine u austrijskoj Koruškoj u svetlu istorijskih i socialnogeografskih procesa. - Globus 12 (1977), str. 56-88. (soavtor M. Klemenčič)

Regionalna preobrazba $s$ Slovenci poseljenega območja ob italijanskojugoslovanski meji v Italiji. - Geografski vestnik 49 (1977), str. 149-156.

Službeniot avstriski popis na naselenieto po vtorata svetska vojna vo pogled na slovenačkoto malcinstvo i slovenečkiot jazik kako govoren jazik vo svetlinata na zakonot za popis na naselenieto od poseben vid. - V: Prisilna asimilacija na slovenečkoto i hrvatskoto malcinstvo vo Avstriji. Skopje 1977, str. 74-89.

\section{8}

Aktualni socialnogeografski problemi Zgornjega Posočja. - V: Zgornje Posočje. Zbornik 10. zborovanja slovenskih geografov, Tolmin - Bovec, 26. - 28. 9. 1975. Ljubljana 1978, str. 127-135. (soavtorji M. Pak ...[et al.])

Considerazioni per la valutazione dei problemi socio-economici ed ambientali degli Sloveni in Italia. - V: Atti del Simposio sui problemi socioeconomici e ambientali degli Sloveni in Italia. Vol. 1. Trieste 1978, str. 5-21. (soavtor K. Šiškovič)

Geografski problemi življenjskega okolja : jugoslovanski simpozij z mednarodno udeležbo. - Naše okolje 3 (1978), št. 5-6, str. 179.

Grenzregionen und nationale Minderheiten. - V: Socialnogeografski problemi obmestnih in obmejnih območij. Ljubljana 1978, str. 7-20. (Geographica Slovenica ; 8).

Karakter, uzroci i posledice iseljavanja iz Jugoslavije. - V: Iseljeništvo naroda i narodnosti Jugoslavije. - Zagreb 1978, str. 105-110.

Migracije kao faktor populacionih i prostornih promena na primeru Slovenije. Migracije 7 (1978), št. 11, str. 23-38. (soavtor A. Gosar)

Le migrazioni quale fattore di cambiamento delle strutture demografiche e spaziali : I'esempio della Slovenia. - V: Italiani in movimento. Pordenone 1978, str. 141-151. (soavtor A. Gosar)

Ob 15-letnici Inštituta za geografijo Univerze v Ljubljani. - Raziskovalec 8 (1978), št. 2-4, str. 138-148. 
Ob petnajstletnici ustanovitve Inštituta za geografijo Univerze $\mathbf{v}$ Ljubljani = Fifteen years of the Institute of geography at the University of Ljubljana. - V: Socialnogeografski aspekti obmejnih območij Slovenije. Ljubljana 1978, str. 5-15. (Geographica Slovenica ; 6).

Razvoj prebivalstva v Zgornjem Posočju v primerjavi s celotno Slovenijo. - V: Zgornje Posočje. Zbornik 10. zborovanja slovenskih geografov, Tolmin - Bovec, 26. 28. 9. 1975. Ljubljana 1978, str. 137-142.

\section{9}

Delo Inštituta za geografijo Univerze Edvarda Kardelja v letih 1977 - 1978 . Geografski vestnik 51 (1979), str. 171-177.

Die Lage und die Bedeutung Sloweniens im Rahmen der grenzüberschreitenden Fremdenverkehrsströme. - V: Tourism and borders. Proceedings of the Meeting of the IGU Working Group Geography of Tourism and Recreation, Ljubljana / Trieste, 15. - 19. 9. 1978. Frankfurt am Main 1979, str. 15-19.

O problemu organiziranosti na medjurepubličkoj osnovi za istraživački rad o problematici povratka radnika sa privremenog rada u inostranstvu. - V: Suvremeno stanje vanjskih migracija iz Jugoslavije i njihovo naučno istraživanje. Zagreb 1979, str.132-133. (Rasprave o migracijama ; 60).

Problemi prebivalstva $\mathbf{v}$ socialnogeografskem razvoju mariborske regije $\mathbf{v}$ primerjavi s celotno Slovenijo. - V: Mariborsko Podravje. Zbornik 11. zborovanja slovenskih geografov, Maribor, 28. - 30. 6. 1978. Maribor 1979, str. 127-140.

Urbanizzazione spaziale e minoranze etniche nel Centro Europa. - V: Conferenza internazionale sulle minoranze, 10-14 luglio 1974. Trieste 1979, str. 59-69.

\section{0}

Neki socijalni uzroci i posledice prostornih uticaja industrializacije Slovenije. V: Urbana in industrijska geografija. Jugoslovanski geografski simpozij, Ljubljana, 8. - 10. 11. 1979. Ljubljana 1980, str. 275-284.

Obmejna regija. - V: Vodnik po ekskurziji. 5. jugoslovanski simpozij o pouku geografije. Ljubljana 1980, str. 1-10. 
The problems of the semi-agrarian structure in the semi-urban zones of Slovenia $=$ Problemi polkmečke strukture $\mathbf{v}$ obmestjih Slovenije. - V: Geografski problemi obmestij. 2. poljsko - jugoslovanski seminar, Varšava, 29. 5. - 3. 6.1978. Ljubljana 1980, str. 9-21. (Geographica Slovenica; 11).

Sodobni pomen geografije v vzgojnoizobraževalnem procesu. - Geografski obzornik 27 (1980), št. 1-2, str. 9-11.

Stališča Mihajla Idvorskega Pupina do znanosti, njene organizacije in povezovanja le-te s pedagoškim procesom na univerzi ter prakso od konca 19. do prve četrtine 20. stoletja. V: Mihajlo I. Pupin - znanstvenik, politik, gospodarstvenik. Ljubljana 1980, str. 36-40.

Strukturveränderung und innergemeindliche Differenzierung in den Gemeinden Ohrid, Struga und Resen. - V: Räumliche Struktur- und Prozessmuster in der SR Makedonien. Kallmünz/Regensburg 1980, str. 59-64. (Münchner Studien zur Sozialund Wirtschaftsgeographie ; 20).

Adamič v procesu množičnega izseljevanja s slovenskega etničnega ozemlja. - V: Louis Adamič. Simpozij, Ljubljana, 16. - 18. september 1981. Ljubljana 1981, str. 2330. (soavtor R. Genorio)

Industrialisierung und raumwirksame Urbanisierung in Slowenien Jugoslawien. - V: Industrialisierung und Urbanisierung in sozialistischen Staaten Südosteuropas. Kallmünz / Regensburg 1981, str. 27-35. (Münchner Studien zur Sozial- und Wirtschaftsgeographie ; 21).

Die Kulturlandschaft im nordwestlichem Grenzgebiet Jugoslawiens (SR Slowenien). - Regio basiliensis 22 (1981), št. 2-3, str. 217-231.

Poselitev in razvoj prebivalstva na Gorenjskem $\mathbf{v}$ zadnjih treh desetletjih. - V: Gorenjska. Zbornik 12. zborovanja slovenskih geografov, Kranj - Bled, 15. - 17. 10. 1981. Ljubljana 1981, str. 55-63.

Razprava o geografiji. - Geografski vestnik 53 (1981), str. 85-92. (soavtorji I. Vrišer ...[et al.]) 
Dvajset let dela Inštituta za geografijo $v$ luči prispevka $k$ razvoju slovenske geografije. - V: 20 let socialne geografije $\vee$ Sloveniji. Ljubljana 1982, str. 7-15. (Geographica Slovenica ; 13).

The elements of regional integration in border areas. - V: Cooperations and conflict in border areas. Milano 1982, str. 61-71. (soavtor I. Piry)

Geografia : [libro di testo sperimentale]. - Ljubljana 1982, 113 str. (Istruzione media fondo comune di contenuti educativi e istruttivi base). (soavtorji S. Brinovec ...[et al.])

Geografija : [poskusni učbenik]. - Ljubljana, 1982, 113 str. (Srednje izobraževanje skupna vzgojnoizobrazbena osnova). (soavtorji S. Brinovec ...[et al.])

Gravitacijsko zaledje dijakov Zvezne gimnazije za Slovence v Celovcu. - V: Jubilejni zbornik. 25 let Zvezne gimnazije za Slovence v Celovcu. Celovec 1982, str. 110-115.

Urbanizacija in deagrarizacija ter izraba zemlje za proizvodnjo hrane. - V: Geografske značilnosti preobrazbe slovenskega podeželja. Ljubljana 1982, str. 41-48.

\section{3}

Nekatere značilnosti regionalnega razvoja alpskega sveta v Sloveniji : poselitev in struktura prebivalstva. - V: Usmerjanje regionalnega razvoja Slovenije. Slovenske Alpe, Severovzhodna Slovenija, Bela krajina. Ljubljana 1983, str. 12-19. (Geographica Slovenica ; 14).

Population growth in the Slovene Alpine area : with the special reference to western Upper Carniola. - Geographica Iugoslavica 5 (1983), str. 91-97.

Regionalno in socialno poreklo dijakov Zvezne gimnazije za Slovence $v$ Celovcu v šolskem letu 1982/1983. - Letno poročilo Zvezne gimnazije za Slovence v Celovcu $26(1982 / 83)$, str. 66-73.

Tri strokovno-znanstvena srečanja geografov iz Slovenije in iz ZR Nemčije : (od 2. do 9. 10. 1983). - Raziskovalec 13 (1983), št. 12, str. 517-518. (soavtor A. Gosar) 
Vprašanja okrog interpretacije rezultatov jugoslovanskega popisa prebivalstva po narodnosti leta 1981. - Razprave in gradivo 1983, št. 16, str. 147-156. (soavtorja R. Genorio, A. Stergar)

\section{4}

Funkcija in položaj jezika Slovencev v zamejstvu ter narodnosti v SR Sloveniji. V: Dvojezičnost - individualne in družbene razsežnosti. Ljubljana 1984, str. 27-31.

Geographische Probleme der Grenzräume Sloweniens. - Österreich in Geschichte und Literatur mit Geographie 28 (1984), št. 6, str. 387-400.

Ob 25-letnici Zvezne gimnazije za Slovence v Celovcu. - V: Koroški Slovenci v Avstriji včeraj in danes. Ljubljana, Celovec 1984, str. 92-94.

Položaj slovenske manjšine na avstrijskem Koroškem v luči historičnih in socialnogeografskih procesov. - V: Koroški Slovenci v Avstriji včeraj in danes. Ljubljana, Celovec 1984, str. 95-111. (soavtor M. Klemenčič)

Poselitev in regionalna struktura prebivalstva vzhodne Dolenjske z Belo krajino. - V: Dolenjska in Bela krajina. Prispevki za 13. zborovanje slovenskih geografov v Dolenjskih toplicah od 12. - 14. oktobra 1984. Ljubljana 1984, str. 193-208. (soavtorja D. Perko, D. Počkaj)

Probleme der regionalen Bevölkerungsentwicklung in der Alpenwelt Jugoslawiens. - V: Raumstrukturen der randalpinen Bereiche Bayerns und Sloweniens. Kallmünz/Regensburg 1984, str. 19-27. ( Münchner Studien zur Sozialund Wirtschaftsgeographie ; 27).

Les problemes du développment et de la répartition de la population dans les Alpes yougoslaves. - V: Les Alpes. Paris 1984, str. 110-114.

1985

Položaj italijanske in madžarske narodnosti in narodnostno mešana območja v slovenski Istri in Prekmurju v luči socialne geografije. - V: Narodnostno mešana območja v SR Sloveniji. Prekmurje, Slovenska Istra. Ljubljana 1985, str. 7-11. (Geographica Slovenica ; 16).

Slovenci smo svetovni narod. - Vestnik koroških partizanov 19 (1985), št. 3-4, str. 516. 
Slovenci smo svetovni narod : pogovor s prof. dr. Vladimirjem Klemenčičem o vprašanjih zamejskih, posebej koroških Slovencev. - Slovenski vestnik 40 (1985), št. $31-32$, str. 6 .

Slovenci smo svetovni narod : pogovor uredništva Zdravstvenega vestnika s prof. dr. Vladimirjem Klemenčičem. - Zdravstveni vestnik 54 (1985), št. 6, str. 282-285.

Uloga M. I. Pupina u borbi za jugoslovenske granice posle prvog svetskog rata. V: Život i delo Mihajla Idvorskog Pupina. Zbornik radova naučnog skupa, Novi Sad Idvor, 4 - 7 oktobar 1979. Novi Sad 1985, str. 391-397. (soavtor M. Klemenčič)

\section{6}

Dvojezičnost v SR Sloveniji (na narodnostno mešanem ozemlju v Prekmurju). Geografski obzornik 33 (1986), št. 2-3, str. 86-95. (soavtor F. Hajós)

Funkcija položaja jezika Slovencev v zamejstvu in narodnosti v SR Sloveniji. Geografski obzornik 33 (1986), št. 2-3, str. 101-104.

Geografija 1. - Ljubljana, 1986, 123 str. (Srednje izobraževanje. Skupna vzgojnoizobrazbena osnova). (soavtorji S. Brinovec ...[et al.])

Die Industrialisierung im Karstgebiet von Slowenien. - V: Angewandte Sozialgeographie. Augsburg 1986, str. 117-128. (Beiträge zur angewandten Sozialgeographie. Sonderband).

Italijansko prebivalstvo na narodnostno mešanem ozemlju na Koprskem v SR Sloveniji. - Geografski obzornik 33 (1986), št. 2-3, str. 96-100.

Izhodiščna načela za vrednotenje sociogospodarskih in prostorskih problemov Slovencev v Italiji. - Geografski obzornik 33 (1986), št. 2-3, str. 9-20. (soavtor K. Šiškovič)

Koroški Slovenci danes. - Geografski obzornik 33 (1986), št. 2-3, str. 51-57.

Koroški Slovenci danes. - Obzornik. Mesečna revija Prešernove družbe 34 (1986), št. 5, str. 342-350.

Kulturna pokrajina v obmejnih območjih severozahodne Jugoslavije na območju Slovenije. - Geografski obzornik 33 (1986), št. 2-3, str. 105-116. 
Nemci v statistiki v jugoslovanski Sloveniji med obema vojnama. - Zgodovinski časopis 40 (1986), št. 4, str. 465-470.

Položaj slovenske manjšine na avstrijskem Koroškem $\mathbf{v}$ luči historičnih in socialno-geografskih procesov. - Geografski obzornik 33 (1986), št. 2-3, str. 30-50. (soavtor M. Klemenčič)

Popis prebivalstva 1981 ne daje objektivne podobe o Koroški. - Slovenski vestnik 41 (1986), št. 1, str. 2.

Problem narodnosti in narodnih manjšin $\mathrm{v}$ procesu urbanizicije $\mathrm{z}$ vidika geografije in etnologije. - V: O razmerju med geografijo in etnologijo. Ljubljana 1986, str. 45-53. (Dela / Oddelek za geografijo Filozofske fakultete ; 3).

Prostorski dejavniki za lokacijo proizvodnih celic na območju KS Črne na Koroškem. - V: Geografsko proučevanje uvajanja celične proizvodnje na Koroškem. Ljubljana 1986, str. 1-27. (Dela / Oddelek za geografijo Filozofske fakultete ; 2).

Slovenska in italijanska narodna manjšina $v$ luči urbanizacije in odprte jugoslovansko-italijanske državne meje. - Geografski obzornik 33 (1986), št. 2-3, str. 21-29.

Statistični prikaz dvojezičnega šolstva, mreže in strukture šol za pripadnike slovenske narodne skupnosti na Koroškem. - Geografski obzornik 33 (1986), št. 23 , str. 58-71. (soavtor T. Domej)

1987

Dileme o vsebini in položaju regionalne geografije v sistemu znanosti. - Teorija in metodologija regionalne geografije. Ljubljana 1987, str. 14-22. (Dela / Oddelek za geografijo Filozofske fakultete ; 4).

Dorferneurung in Jugoslawien. - V: Leben und Wirtschaften im Dorf . 1. Europäischer Dorferneuerungskongress im Rahmen der Europäischen Kampagne für den ländlichen Raum, vom 16. bis 18. November 1987, Weinkolleg Kloster und Krems-Stein, Niederösterreich. Wien 1987, str. 96-101.

Državna granica kao geografski fenomen. - V: Geografski problemi pograničnih regija naše zemlje, Vranje, 28. - 30. maj 1987. Vranje 1987, [23 str.].

Državna meja na območju SR Slovenije in obmejna območja kot geografski fenomen. - Razprave in gradivo 1987, št. 20, str. 57-79. 
Geografija 1. - Ljubljana, 1987, 123 str. (Srednje izobraževanje. Skupna vzgojnoizobrazbena osnova). (soavtorji S. Brinovec ...[et al.])

Grenzüberschreitende raumwirksame Leitbilder dargestellt an Beispielen der Grenzräume Sloweniens in Jugoslawien. - Revue geographique de l'Est 27 (1987), št. 1-2, str. 27-38. (soavtor A. Gosar)

A magyar nemzetiség által lakott vegyes nemzetiségü terület bemutatása a szlovén szk társadalmi gazdasági fejlesztési politikájának és a regionális feltételeknek a tükrében. - V: Magyarok és szlovének. Budapest 1987, str. 43-115. (soavtorja N. Vilhar, S. Devetak)

Najnovije tendencije promene kulturnog pejsaža Slovenije. - V: Zbornik 12. kongresa geografa Jugoslavije. Novi Sad 1987, str. 216-220.

Nekaj pogledov na učinkovitost geografije za družbeno prakso. - Geografski glasnik 49 (1987), str. 24-28.

Neki problemi razvitka i funkcije geografije u Jugoslaviji (u svetlu geografskih problema pograničnih delova naše zemlje). - V: Idejne i društvene vrednosti geografske nauke. Beograd 1987, str. 238-243.

Paradoks sodobne Evrope : koroški pedagoški model dvojezičnega šolstva. Vestnik koroških partizanov 21 (1987), št. 1-4, str. 3-10.

Prikaz narodnostno mešanega ozemlja, kjer živi madžarska narodnost, v luči politike družbeno-gospodarskega razvoja SR Slovenije in regionalnih okoliščin. V: Madžari in Slovenci - sodelovanje in sožitje $\mathrm{v}$ obmejnem območju ob jugoslovansko-madžarski meji. Ljubljana 1987, str. 47-129. (soavtorji N. Vilhar, S. Devetak)

Socialnoekonomske in prostorske funkcije narodnostne pomešanosti Slovencev kot manjšine v sosednjih državah ter Madžarov in Italijanov v SR Sloveniji. Geografski obzornik 34 (1987), št. 2, str. 81-84.

Spreminjanje načina poselitve in strukture prebivalstva na Notranjskem $\mathbf{v}$ zadnjih dveh desetletjih (1961-1981). - V: Notranjska. Zbornik 14. zborovanja slovenskih geografov, Postojna, 15. - 17. oktobra 1987. Postojna 1987, str. 315-330.

SR Slovenija $\mathbf{v}$ luči socialno-prostorske preobrazbe. - V: Zbornik. 10. Derčevi pediatrični dnevi, Ljubljana 11. - 13. 6. 1987. Ljubljana 1987, str., 63-72. 
Causes of social-geographic changes and valuation of urbanization in ruralurban migrational processes in Slovenia. - V: Development and redistribution of population and labour force in agrarian regions of European socialist and capitalist countries. Greifswald 1988, str. 43-54. (Greifswalder geographische Arbeiten ; 6).

Die Deutschen in der Statistik des jugoslawischen Slowenien zwischen den beiden Weltkriegen. - V: Geschichte der Deutschen im Bereich des heutigen Slowenien 1848-1941. Wien 1988, str. 241-247. (Schriftenreihe des Österreichischen Ost- und Südosteuropainstituts ;

13).

Družbeno-gospodarska preobrazba slovenskega prostora. - Vestnik koroških partizanov 22 (1988), št. 3-4, str. 40-54.

Družbeno-gospodarska preobrazba slovenskega prostora. - V: Zbornik predavanj. 14. seminar slovenskega jezika, literature in kulture. Ljubljana 1988, str. 179-190.

\section{9}

The function of borders and the development of border regions within Yugoslavia. - Geographica Iugoslavica 10 (1989), str. 323-337.

Geografija 1. - Ljubljana, 1989, 123 str. (Srednje izobraževanje. Skupna vzgojnoizobrazbena osnova). (soavtorji S. Brinovec ...[et al.])

Granična i centralna područja Jugoslavije u svetlu geopolitičkog istraživanja. V: Jugoslovenski geoprostor. Beograd 1989, str. 93-104.

Ländliche Räume Jugoslawiens im Spannungsfeld zwischen Abwanderung und Verdichtungsprozessen. - V: Landesentwicklung und Umweltschutz im Donauraum. München 1989, str. 46-58. (Südosteuropa aktuell ; 6).

Med antropogeografijo in socialno geografijo na ljubljanski univerzi. - V: Geografija in aktualna vprašanja prostorskega razvoja. Ljubljana 1989, str. 22-29. (Dela / Oddelek za geografijo Filozofske fakultete ; 6).

Oddelek za geografijo. - V: Zbornik Filozofske fakultete v Ljubljani 1919-1989. Ljubljana 1989, str. 113-117. 
Razprava o geografiji. - V: Družboslovje na Slovenskem. Ljubljana 1989, str. 768771.

Slovenes in Australia. - V: Slovenski koledar '90. Ljubljana 1989, str. 193-198. (soavtor M. Račič)

\section{0}

Družbeno-gospodarska preobrazba skupnega slovenskega prostora. - V: Slovenski koledar '91. Ljubljana 1990, str. 85-91.

Geografija 1. - Ljubljana, 1990, 119 str. (Srednje izobraževanje). (soavtorji S. Brinovec ...[et al.])

Die Grenzregion entlag der jugoslawisch-italienischen Grenze : ein Beispiel einer Grenze, die unterschiedliche gesellschaftlich-politische Systeme trennt. - V: Regionalpolitik in Europa. Das Beispiel der peripheren, grenznahen Gebiete. Bayreuth 1990, str. 67-84 . (Arbeitsmaterialien zur Raumordnung und Raumplanung ; 86).

Koprsko kot obmejno, narodnostno mešano in terciarizirano območje. - V: Primorje. Zbornik 15. zborovanja slovenskih geografov, Portorož, 24. - 27. oktobra 1990. Ljubljana 1990, str. 99-105.

Der ländliche Raum und die neuen Wirtschaftsstrategien in Slowenien. - V: Verstärkte internationale Zusammenarbeit der EG-Länder mit Südosteuropa. Bayreuth 1990, str. 55-68. (Arbeitsmaterialien zur Raumordnung und Raumplanung ; 84). (soavtor A. Gosar)

Metodologija uradnih popisov prebivalstva pripadnikov slovenske manjšine $\mathbf{v}$ Italiji, Avstriji in na Madžarskem. - V: Narodne manjšine. Zbornik referatov in razprav na znanstvenem srečanju 30. in 31. marca 1989. Ljubljana 1990, str. 31-45.

O prostornoj relevantnosti migracija stanovništva na primeru Slovenije. - V: Pogledi na migracije stanovništva Jugoslavije. Beograd 1990, str. 167-173.

Raziskovalno delo na področju nacionalnega vprašanja, manjšinskih problemov in mednacionalnih odnosov. - Razprave in gradivo 1990, št. 23, str. 94-100.

Sodobni regionalni problemi madžarske in italijanske narodnosti $\mathrm{v}$ procesih družbeno-ekonomske preobrazbe. - Razprave in gradivo 1990, št. 23, str. 52-61. 
Tromeja - obmejna regija Jugoslavije, Avstrije in Italije : mednarodni meduniverzitetni geografski raziskovalni projekt $=$ Das Dreiländereck - eine Grenzregion Österreichs, Italiens und Jugoslawiens = Le Tre regioni di confine un'area transconfinaria tra Italia, Jugoslavia ed Austria. - Ljubljana 1990, 184 str. (Dela / Oddelek za geografijo Filozofske fakultete ; 7). (soavtorji A. Gosar ... [et al.])

Vodila za razvoj Inštituta za narodnostna vprašanja in teze za povezovanje štirih inštitutov. - Razprave in gradivo 1990, št. 23, str. 15-18.

\section{1}

Confine politico ed aree di confine: il caso della Republica di Slovenia. - V: Colloque International L' effet frontiere dans les Alpes, St.Vincent / Val d'Aoste, 1988. [Aoste] 1991, str. 174-180.

Geografija 1. - Ljubljana, 1991, 119 str. (Srednje izobraževanje). (soavtorji S. Brinovec ...[et al.])

Geographic problems of frontier regions : the case of the Italo-Yugoslav border landscape. - V: The geography of border landscapes. London, New York 1991, str. 86-103. (soavtor M. Bufon)

Prekmurje als unterentwickeltes Grenzgebiet Sloweniens. - V: Regionalforschung von grenzüberschreitender Bedeutung. Kärnten-Slowenien / Kroatien. Wien 1991, str. 33-50. (Mitteilungen des Arbeitskreises für neue Methoden in der Regionalforschung ;22).

Prekmurje kot nerazvito obmejno območje v Sloveniji. - V: Geografska problematika Severovzhodne Slovenije. Ljubljana 1991, str. 108-124 (Dela / Oddelek za geografijo Filozofske fakultete ; 8)

Sodobni regionalni problemi madžarske narodnosti $\mathbf{v}$ procesih družbenoekonomske preobrazbe. - V: Vzporednice slovenske in hrvaške etnologije 7. Ljubljana 1991, str. 61-69. (Knjižnica Glasnika slovenskega etnološkega društva ; 21).

Spreminjanje nacionalne strukture prebivalstva Jugoslavije $\mathbf{v}$ novejšem razdobju. - Geografija v šoli 1 (1991), št. 1, str. 7-22.

Tendence spreminjanja slovenskega podeželja. - Geografski vestnik 63 (1991), str. 25-40. 
Državna meja na območju $R$ Slovenije in mejna območja kot nov geografski fenomen. - V: Seminar za študije geopolitičnega položaja Slovenije. Ljubljana 1992, str. 81-105.

Gegenwärtige politische, sozial- und wirtschaftsgeographische Probleme als Ausgangsbasis für die Integration Sloweniens in Europa. - V: Slowenien auf dem Weg in die Marktwirtschaft. Bayreuth 1992, str. 4-18. (Arbeitsmaterialien zur Raumordnung und Raumplanung ; 108).

Geografija 1. - Ljubljana, 1992, 119 str. (Srednje izobraževanje). (soavtorji S. Brinovec ...[et al.])

Geopolitični položaj Slovenije in njena odprtost v Evropo. - Geografija v šoli 2 (1992), št. 2, str. 15-24.

Geopolitični položaj Slovenije in njena odprtost $\mathbf{v}$ Evropo. - V: Zbornik kongresnih gradiv in referatov. 1. slovenski kongres o cestah in prometu, Bled, 21. in 22. oktobra 1992. Bled 1992, str. 93-100. (soavtor R. Genorio)

Die geopolitische Lage Sloweniens und seine Offenheit nach Europa. - V: Staatliche Einheit und Teilung - Deutschland und Jugoslawien. München 1992, str. 99-114. (Südosteuropa aktuell ; 14).

Nova država Slovenija in njena funkcija v združeni Evropi. - V: Okrogla miza o vplivu geopolitičnega položaja Slovenije na strategijo razvoja Slovenije. Ljubljana 1992, str. 43-63. (soavtor R. Genorio)

Settling pattern and demographic structure of Slovenia. - V: Slovenia. Geographic aspects of a new independent European nation. Ljubljana 1992, str. 41-49

Slovenija in obmejna območja. - Geografski obzornik 39 (1992), št. 1, str. 17-19.

Slovenija in Slovenci danes ter jutri $\mathbf{v}$ luči socialne geografije. - V: Socialna geografija $v$ teoriji in praksi. Ljubljana 1992, str. 37-56. (Geographica Slovenica ; 23).

Regionalizem - nov izziv za geografijo : primer slovenskega etničnega ozemlja. Geografski vestnik 64 (1992), str. 157-167. (soavtor J. Zupančič)

Wandlungstendenzen im ländlichen Raum Sloweniens. - V: Ländliche Räume im Umbruch - Chancen des Strukturwandels. - München 1992, str. 99-110. (Münchner Universitäts-Schriften. Münchner Studien zur Sozial und Wirtschaftsgeographie ; 37). 
Current problems of regional development of Slovenia. - V: Development strategies in the Alps-Adriatic region. Pecs 1993, str. 143-163. (soavtor M. Ravbar)

Geografija 1. - Ljubljana, 1993, 110 str. (Srednje izobraževanje). (soavtorji S. Brinovec ...[et al.])

Geopolitični položaj in regionalizem na primeru jugozahodne Slovenije. Annales. Anali Koprskega primorja in bližnjih pokrajin 1993, št. 3, str. 203-210.

Geopolitični položaj Slovenije in njena odprtost $\mathbf{v}$ Evropo. - V: Nacionalna strategija prostorskega razvoja Slovenije. 12. Sedlarjevo srečanje, Postojna, 28. - 29. maj 1992. Postojna 1993, str. 31-37.

Geopolitični položaj Slovenije in teoretično metodološke osnove za opredelitev tipov obmejnih območij. - V: Geografski aspekti obmejnosti in regionalnega razvoja. Ljubljana 1993, str. 9-20. (Dela / Oddelek za geografijo Filozofske fakultete ; 10).

Jugoslawien : Zerfall und Bildung neuer Staaten. - V: Europa. Neue Konturen eines Kontinents. München 1993, str. 213-223. (Aspekte der Geographie).

Narodne manjšine kot element demografske in prostorske stvarnosti $\mathbf{v}$ alpskojadransko-panonskem prostoru. - V: Geografija in narodnosti. Ljubljana 1993, str. 19-31. (Geographica Slovenica ; 24).

National minorities as an element of the demographic and spatial structure of the Alpine-Adriatic-Pannonian region. - GeoJournal 30 (1993), št. 3, str. 207-214.

The new state of Slovenia and its function within the frame of Europe. GeoJournal 30 (1993), št. 3, str. 323-333. (soavtor R. Genorio)

Novi pogledi geografa Jerneja Zupančiča na položaj slovenske manjšine na avstrijskem Koroškem. - Letno poročilo Zvezne gimnazije in Zvezne realne gimnazije za Slovence v Celovcu 36 (1992/93), str. 66-73.

Problemy mniejśzosci narodowych w krajach powstalych w poludniowej strefie dawnej monarchii habsburskiej $=$ The problems of national minorities in the countries originated in the southern zone of the former Habsburg monarchy. - V: Studia Śląskie 52 (1993), str. 113-131.

Slovenia and the process of European integration. - Slovenija 7 (1993), št. 1, str. 34-37. (soavtor R. Genorio) 
Slovenia at the European ethnic crossroads. - V: Ethnic minorities in Slovenia. Ljubljana 1993, str. 6-12.

Slovenski geografi v tujem znanstvenem tisku. - Geodetski vestnik 37 (1993), št. 1, str. 72-73.

Slovenski geografi v tujem znanstvenem tisku. - Geografski obzornik 40 (1993), št. 2 , str. 3.

Sporočilo z okrogle mize o vplivu geopolitičnega položaja Slovenije na strategijo razvoja Slovenije. - Geografski obzornik 40 (1993), št. 1, str. 34-36. (soavtorja D. Nendl, M. Kos)

Tradition und Fortschritt : die Volksgruppen in der Industriegeselschaft. - V: Brücken statt Mauern. Minderheiten in Zentraleuropa. Wien 1993, str. 154-167.

Vodnik po razstavi : objave del slovenskih geografov $v$ svetovnem tisku $=$ Guide to the exhibition : Slovenian geographers in foreign publications. - Mednarodno posvetovanje geografija in narodnosti, Ljubljana, Slovenija: 8. - 11. September 1993. Program, povzetki in vodnik = Symposium on ethnicity and geography, Ljubljana, Slovenia: September 8 - 11, 1993. Programme, abstracts and guide. Ljubljana 1993, [4 str., loč. pag.]. (soavtor J. Zupančič)

Die wirtschaftliche und politische Lage der jungen Republik Slowenien. - V: Die "neuen" Nachbarstaaten Österreichs. Wien 1993, 11 str.

\section{4}

Borderlands and regionalism in the space settled by Slovenians - a case study. V: Inner divisions, region and regionalism. No. 1. Lodz, Opole 1994, str. 33-43. (soavtor J. Zupančič)

Cultural elements of integration and transformation of border regions : the case of Slovenia. - Political geography 13 (1994), št. 1, str. 73-83. (soavtor M. Bufon)

Current problems of border regions along the Croato-Slovene frontier. - V: Documentation. Political boundaries and coexistence. Basel 1994, str. [18]. (soavtor A. Gosar) 
Current problems of border regions along the Slovene-Croatian border. - V: Political Boundaries and Coexistance. Proceedings of the IGU-Symposium, Basle / Switzerland, 24 - 27 May 1994. Bern [etc.] 1994, str. 30-42. (soavtor A. Gosar)

Der Einfluss der Veränderungen der Verlaufs der Staatsgrenzen auf die regionale Entwicklung des Oberen Isonzo. - V: Isonzo-Protokoll. Klagenfurt [etc.] 1994, str. 251-263.

The European integration from the Slovenian view point. - V: European challenges and Hungarian responses in regional policy. Pecs 1994, str. 67-78. (soavtor A. Gosar)

Funkcija narodnih manjšin $v$ prekomejnem meddržavnem povezovanju in evropski integraciji. - V: Narodne manjšine danes in jutri. Trieste 1994, str. 97-107.

Geografija 1. - Ljubljana, 1994, 119 str. (Srednje izobraževanje). (soavtorji S. Brinovec ...[et al.])

Narodne manjšine kot element politične, prostorske, socialne in ekonomske stvarnosti $\mathbf{v}$ alpsko-jadransko-panonskem prostoru. - V: Manjšine $\mathrm{v}$ prostoru Alpe-Jadran. Ljubljana 1994, str. 1-8.

National minorities as an element of the demographic and spatial structure of the Alpine-Adriatic-Pannonian region. - V: GeoJournal Reprint 1994, str. 207-214.

Območja avtohtone in alohtone poselitve Slovencev. - Glasnik Unescol4 (1994), št. 42, str. 51. (soavtor Z. Drole)

Prostorsko-strukturne spremembe Slovenije kot nove države. - Znanstvena revija. Družboslovje in filozofija 6 (1994), št. 1, str. 67-84.

Überlebensmöglichkeiten der nicht anerkannten Minderheit der Slowenen in der Steiermark. - V: Steirische Slowenen. Zweisprachigkeit zwischen Graz und Maribor, Graz, 7.

und 8. Juni 1994. Graz 1994, str. 81-90.

Učinki sprememb poteka državnih meja na regionalni razvoj Zgornjega Posočja. - V: Soški protokol. Celovec [etc.] 1994, str. 215-226.

Vloga slovenske geografije $\mathrm{v}$ mednarodni promociji Slovenije od prvih večstrankarskih parlamentarnih volitev do danes. - V: Vloga slovenske geografije $\mathrm{v}$ mednarodni promociji Slovenije. Bibliografija $\mathrm{v}$ tujini objavljenih del slovenskih geografov 1989-1994. Ljubljana 1994, str. 3-4. 
Pomen slovenskega manjšinskega šolstva $v$ sodobnih procesih evropske integracije. - V: Čedermaci današnjega dne. Pričevanja o slovenski šoli in materinščini v zamejstvu. Ljubljana 1995, str. 11-29.

Prostorska diferenciacija Republike Slovenije po demografskih procesih in demografskih strukturah. - V: Regionalni vidiki demografske politike Slovenije. Strokovni posvet, Ljubljana, 27. junij 1995. Ljubljana 1995, str. 24-29.

Structures nationales des groupes ethniques et des minorités nationales dans l'Eurorégion Alpe-Adria. - V: Langues régionales et relations transfrontalieres en Europe. Paris 1995, str. 173-187. (Géographie et cultures). (soavtor M. Klemenčič)

Szlovénia és Magyarország közös problémái a geopolitikai helyzet és az európai integráció tükrében. - Földrajzi Értesítö 44 (1995), št. 3-4, str. 281-288.

Vloga slovenske geografije $\mathbf{v}$ mednarodni predstavitvi Slovenije. - Geografski vestnik 67 (1995), str. 121-126.

Der Wandel des ländlichen Raumes in Slowenien aus sozialgeographischer Sicht. - V: Der Wandel des ländlichen Raums in Südosteuropa. München, Leipzig 1995, str. 103-113. (Südosteuropa aktuell ; 19).

\section{6}

Causes and consequences of emigration from Slovenia and the broader AlpineAdriatic-Pannonian / Danubian region in the last hundred years. - V: Les réseaux des diasporas $=$ The networks of diasporas. Nicosia 1996, str. 323-334. (Géographie et cultures).

Geopolitical situation and regionalism showed in the example of southwest Slovenia. - V: Slovenia. A gateway to Central Europe. Published on the occasion of the 28th International Geographical Congress, The Hague, August 5 - 10, 1996. Ljubljana 1996, str. 57-62.

Razvoj in položaj slovenske manjšine $\mathbf{v}$ Kanalski dolini $\mathbf{v}$ luči evropske integracije. - V: Večjezičnost na evropskih mejah - primer Kanalske doline. Ukve 1996, str. 59-75. 
Tendence demografske preobrazbe $v$ Spodnjem Podravju in vzhodnih Slovenskih goricah v zadnjih treh desetletjih. - V: Spodnje Podravje s Prlekijo. Možnosti regionalnega in prostorskega razvoja. 17. zborovanje slovenskih geografov, Ptuj, 23. - 26. oktobra 1996. Ljubljana 1996, str. 201-211. 